\title{
Traditional pineapple production: Scope for scale up to enhance farmers' income
}

\author{
Rajkumari Rameshori Devi*, Dipanjan Kashyap", H. Aisolia Devi, Jharna Choudhury ${ }^{2}$ and Pithunglo L. Kikon \\ Department of MBA-Agri Business, Assam Agricultural University, Jorhat (Assam) India \\ (Email: rkrameshori@gmail.com)
}

\begin{abstract}
Pineapple is one of the most important horticultural crops in Manipur. The present study was conducted in Senapati, Churachandpur and Imphal West districts of Manipur. The pineapple production was recorded highest in Senapati district, followed by Churachandpur district. Traditionally the farmers use to market their produce for fresh consumption at nearby markets; however with increase in the establishment of small and medium scale processing industries the new marketing channels has evolved in the state. Four important marketing channels have been identified for the trade of pineapples, out of which channel comprising of Farmer - Lalonbi/ Women trader - Retailer was found as the most dominant through which about 64 per cent of the pineapple moved. The average farm productivity and returns to pineapple growers remain low for past few decades due to many bottlenecks. Emerging processing industry in the state will help the farmers in increasing the shelf life of the produce. Moreover, there is a need to develop infrastructural facilities, especially in remote production areas, so that the produce could be reached the market immediately after harvest. Practicing mix cropping could be a big boost among the traditional farmers of the state in the days to come.
\end{abstract}

Key Words : Pineapple, Farmer, Production, Manipur

View Point Article : Devi, Rajkumari Rameshori, Kashyap, Dipanjan, Devi, H. Aisolia, Choudhury, Jharna and Kikon, Pithunglo L. (2021). Traditional pineapple production: Scope for scale up to enhance farmers' income. Internat. J. agric. Sci., 17 (2) : 305-310, DOI:10.15740/ HAS/IJAS/17.2/305-310. Copyright@2021: Hind Agri-Horticultural Society.

Article History : Received : 23.02.2021; Revised : 25.02.2020; Accepted : 15.03.2021

\footnotetext{
* Author for correspondence :

${ }^{1}$ Department of Agril. Economics (MBA- Agri Business), Assam Agricultural University, Jorhat (Assam) India

${ }^{2}$ Biotech Kisan Hub, Krishi Vigyan Kendra (AAU), Darrang (Assam) India
} 